DOI: https://doi.org/10.47405/mjssh.v6i3.690

\begin{tabular}{|c|c|}
\hline Cing & Malaysian Journal of Social Sciences and Humanities (MJSSH) \\
\hline Malaysian Journal of & Volume 6, Issue 3, March 2021 \\
\hline (MJ-sSH) & e-ISSN : 2504-8562 \\
\hline & $\begin{array}{l}\text { Journal home page: } \\
\text { www.msocialsciences.com }\end{array}$ \\
\hline
\end{tabular}

\title{
Kebimbangan dan Efikasi Kendiri Terhadap Pembelajaran Matematik dalam kalangan Pelajar Tingkatan Empat
}

\author{
Er Xiao Hui ${ }^{1}$, Roslinda Rosli ${ }^{1}$ \\ ${ }^{1}$ Fakulti Pendidikan, Universiti Kebangsaan Malaysia (UKM) \\ Correspondence: Er Xiao Hui (p99521@siswa.ukm.edu.my)
}

\begin{abstract}
Abstrak
Pembelajaran matematik masa kini tidak lagi hanya menekankan pembinaan tingkah laku pelajar yang dapat dikesan daripada tindak balas dan rangsangan. Bahkan juga memberi penekanan bagi melihat bahawa pendidikan matematik disifatkan sebagai subjek yang sukar di samping melibatkan interaksi dinamik antara sifat dalaman pelajar, faktor fizikal dan faktor persekitaran sosiobudaya. Persaingan sengit dan perubahan teknologi yang pesat memerlukan kepintaran matematik dan wajib diambil hampir dalam kesemua latar belakang pendidikan. Justeru, kajian ini dijalankan adalah untuk menentukan tahap kebimbangan dan efikasi kendiri pelajar serta hubungannya berdasarkan pembelajaran matematik. Kajian tinjauan ini melibatkan 311 orang pelajar tingkatan empat yang mengambil mata pelajaran Matematik Tambahan di daerah Johor Bahru. Pensampelan rawak mudah dan berkelompok telah digunakan untuk mendapat responden kajian. Instrumen kajian merupakan soal selidik Mathematics SelfEfficacy and Anxiety Questionaire (MSEAQ) yang telah diadaptasi serta diubahsuai bagi mengukur tahap kebimbangan dan efikasi kendiri terhadap pembelajaran matematik dalam kalangan pelajar Sekolah Menengah Kebangsaan harian. Dapatan menunjukkan kebimbangan pelajar terhadap pembelajaran matematik berada pada tahap yang tinggi. Selain itu, hasil dapatan bagi tahap efikasi kendiri pelajar terhadap pembelajaran matematik pula adalah berada pada tahap sederhana. Hasil analisis ujian korelasi mendapati, tiada perhubungan antara kebimbangan dan efikasi kendiri pelajar terhadap pembelajaran matematik. Kajian ini secara keseluruhannya menunjukkan pembelajaran matematik tidak sekadar bergantung kepada kebolehan kognitif, tetapi juga melibatkan faktor psikologi pelajar. Cadangan penambahbaikan kajian boleh dilakukan melalui penambahan sampel kajian, perluasan konteks dan mengaitkannya dengan pemboleh ubah lain yang berpotensi.
\end{abstract}

Kata kunci: kebimbangan, efikasi kendiri, pembelajaran matematik, matematik tambahan, kognitif

\section{Anxiety and Self-Efficacy Towards Mathematics Learning Among Form Four Students}

\begin{abstract}
Mathematical Learning Disabilities Children with mathematical learning disabilities not only have specific problems in mathematics, but the majority of them also exhibit deficits in general cognitive functioning. Mathematics is a gateway to many scientific and technological fields. Leaving it limits students' opportunities to learn a range of important subjects, thus limiting their future job opportunities and depriving society of a potential pool of quantitatively literate citizens. Thus, this study was conducted to determine the level of math anxiety and self-efficacy of students and its relationship based on
\end{abstract}


mathematical learning. Respondents involved in this study were 311 Form Four students who have learning Additional Mathematics in secondary schools in the state of Johor Bahru. Simple and cluster random sampling was used to obtain study respondents. This survey instruments applied Mathematics Self-Efficacy and Anxiety Questionaire (MSEAQ), who used were specifically for adapted and modified to measure the level of anxiety and self-efficacy on mathematics learning among students of secondary schools. The findings show that students' concerns about learning mathematics are at a moderate level, but approaching high. In addition, the findings for the level of self-efficacy of students on learning mathematics are at a moderate level too. The results of the correlation test analysis found that there was not relationship between students' anxiety and self-efficacy on learning mathematics. This study as a whole shows that learning mathematics not only depends on cognitive abilities, but also involves the psychological factors of students. Suggestions for improving the study can be done through the addition of a study sample, the expansion of the context and relating it to other potential ways.

Keywords: anxiety, self- efficacy, mathematics learning, additional mathematics, cognitive

\section{Pengenalan}

Pembelajaran matematik masa kini bukan lagi hanya menekankan pembinaan tingkah laku pelajar yang dapat dikesan daripada tindak balas dan rangsangan. Bahkan juga memberi penekanan bagi melihat bahawa pendidikan matematik disifatkan sebagai subjek yang sukar di samping melibatkan interaksi dinamik antara sifat dalaman pelajar, faktor fizikal dan faktor persekitaran sosiobudaya. Perubahan teknologi yang pesat dan persaingan sengit memerlukan kepintaran matematik dan wajib diambil hampir dalam kesemua latar belakang pendidikan. Bukan itu saja, Chien dan Denis (2016) serta Schober et al. (2018) juga menyatakan bahawa sukatan pelajaran sentiasa diperbaharui supaya dapat selari dengan kehendak pada zaman berteknologi ini. Justeru, mata pelajaran yang sering pelajar anggapkan subjek yang sukar ialah mata pelajaran Matematik bahkan mustahil untuk dikuasai (Arshad 2017). Kesedaran terhadap kepentingan ilmu matematik juga menjadi keutamaan dan penerapannya sering ditekankan di setiap peringkat umur iaitu daripada kanak-kanak, remaja dan dewasa (Lukowski et al., 2019). Hal ini selari dengan kajian Yahya dan Amir (2018) yang menjelaskan bahawa pengetahuan matematik diperlukan untuk merealisasikan harapan dan impian bagi melahirkan insan yang akan memaju dan membangunkan negara pada masa akan datang.

Kesukaran menguasai pembelajaran matematik bukan hanya bagi mata pelajaran Matematik Tambahan sahaja, tetapi sama juga bagi Matematik Moden yang sentiasa dikaitkan dengan memahami kefahaman terhadap konsep matematik. Sehubungan dengan itu, aspek kefahaman konsep mencakupi kesilapan, salah faham dan juga miskonsepsi mengenai konsep matematik. Jika terdapat penguasaan pengetahuan matematik yang lemah, maka kefahaman terhadap konsep matematik adalah pada tahap yang rendah (Yang et al., 2020). Dalam dunia kini yang berhadapan dengan pandemik COVID-19 serta perubahan mendadak dan tidak dijangkakan, memahami konsep sememangnya merupakan pengasas pengetahuan bagi proses pengajaran dan pembelajaran dalam dunia pendidikan Matematik (Mulenga \& Marban, 2020). Pelajar bukan lagi sebagai individu pasif yang hanya menerima maklumat, tetapi bagi diri mereka perlu terlibat secara aktif dalam aktiviti pembelajaran bagi menghubungkan perkaitan antara maklumat sedia ada dan maklumat yang dipelajari (Sevgi \& Arslan, 2020). Bukan itu sahaja, kesukaran menguasai pembelajaran matematik tidak sekadar menampakkan kesan dari segi fizikal malah turut memberi kesan dari segi psikologi juga (Durken et al., 2017). Mengikut Wang et. al. (2015) dalam kajian Mutlu (2019) pula, menggigil adalah kesan daripada fizikal. Selain itu, kesan daripada psikologi bagi seseorang pelajar adalah mereka rasa tertekan apabila menghadapi peperiksaan matematik turut dijadikan sebagai akibat daripada kesukaran dalam menguasai matematik (Skilling, Bobis \& Martin, 2020). Menurut Wakefield et al. (2018), kesan-kesan sebegini telah mengakibatkan penurunan prestasi pelajar terhadap pembelajaran matematik.

Bukan sekadar subjek Matematik sukar difahami, malah terdapat segelintir pelajar tidak dapat melakukan hubung-kait terhadap hasil pembelajaran matematik dalam kehidupan seharian. Mengikut keterangan 
Marzita dan Khalin (2016), pengajaran dan pembelajaran bagi mata pelajaran Matematik bukannya menekankan pada kaedah kemahiran berfikir sebaliknya menekankan petua, penghafalan, peraturan dan rumus. Ketidakupayaan melakukan perhubungan akan menyebabkan pelajar berasa bimbang dan tertekan serta tidak berminat meneruskan pelajaran, lebih-lebih lagi jika mereka tidak memahami kandungan pelajarannya. Faktor penyebab bagi menyatakan prestasi pelajar terhadap pembelajaran matematik yang kurang memuaskan selalu dikaitkan dengan sikap terhadap matematik (Husain, 2020; Reimer et. al., 2018), faktor motivasi (Chang \& Beilock, 2016; Cribbs et al., 2020), status sosioekonomi (Husain, 2020), efikasi kendiri (Gunderson et al., 2018; Hammoudi, 2020; Huang, Zhang \& Hudson, 2019; Peixoto et. al., 2017) dan juga kebimbangan matematik (Smart \& Linder, 2018; Huang, Zhang \& Hudson, 2019; Yahya \& Amir, 2018). Justeru, pengkaji berhasrat untuk mengisi jurang kajian ini dan meninjau tahap kebimbangan dan efikasi kendiri pelajar terhadap pembelajaran matematik.

Dengan wujudnya situasi pandemik COVID-19 pada masa kini, efikasi kendiri bagi seseorang pelajar sepatutnya ditingkatkan lagi agar dapat menangani perubahan dan kekangan yang mungkin ditemui. Misalnya, individu yang memiliki efikasi kendiri yang tinggi akan lebih komited dalam menghadapi perubahan (Sevgi \& Arslan, 2020). Sebagaimana yang kita ketahui bahawa peningkatan prestasi mata pelajaran Matematik perlu diberi keutamaan kepada kefahaman berkenaan efikasi kendiri pada diri seseorang pelajar. Dengan kata lain, pelajar yang mempunyai tahap keyakinan diri dan motivasi yang tinggi dalam efikasi kendiri dapat menjangkakan sebarang masalah pembelajaran matematik mampu mereka mengatasinya serta mencapai matlamatnya (Gabriel et. al., 2019). Bandura (2010) menyatakan bahawa efikasi kendiri didefinisikan sebagai kecekapan dan keyakinan diri bergantung kepada keupayaan seseorang individu dalam merancang dan melaksanakan sebarang implikasi yang diperlukan bagi menghasilkan sesuatu tugasan yang lebih berkualiti.

Jelaslah bahawa kesan kebimbangan terhadap pembelajaran matematik mengenai domain psikologi akan mempengaruhi keyakinan diri pelajar serta menyebabkan timbulnya perasaan negatif dalam diri pelajar (Bartley \& Ingram, 2017; Dowker et al., 2019). Impak-impak yang dibincangkan bukanlah suatu perkara yang boleh dianggap sebagai perkara yang remeh-temeh. Bahkan, memahami faktor kebimbangan terhadap Matematik dan efikasi kendiri pelajar merupakan sesuatu perkara yang tidak seharusnya dipandang enteng dalam konteks pendidikan di Malaysia. Oleh yang demikian, pengkaji berhasrat untuk menentukan tahap kebimbangan dan efikasi kendiri terhadap pelajar tingkatan empat dalam pembelajaran matematik serta mengenal pasti sama ada terdapat hubungan antara kebimbangan dengan efikasi kendiri pelajar Tingkatan Empat terhadap pembelajaran matematik. Kajian ini amat penting bagi pihak berkenaan seperti ibu bapa, guru serta pelajar sendiri menyedari wujudnya kebimbangan dalam pembelajaran matematik serta keyakinan dan sikap seseorang pelajar perlu dipertingkatkan lagi tanpa memandang rendah akan kepentingan efikasi kendiri. Lanjutan daripada huraian yang telah dinyatakan, langkah intervensi perlu dirangka supaya situasi sebegini dapat dikawal dengan baik serta dapat memberi ruang dan peluang untuk menjayakan kerjaya kelak.

\section{Sorotan Literatur}

\section{Kebimbangan dan Efikasi Kendiri Pelajar dalam Pembelajaran Matematik}

kebimbangan terhadap pembelajaran matematik merujuk kepada perhubungan antara psikologi dan tingkah laku seseorang pelajar terhadap pembelajarannya. Hal ini secara tidak langsung akan mengakibatkan pelajar hilang keyakinan diri dan sering lupa semasa menyelesaikan sebarang masalah berkaitan pengiraan matematik (Batchelor, Torbeyns \& Verschaffel, 2019). Lebih-lebih lagi, Matematik bukan sahaja dikenali sebagai mata pelajaran yang sukar difahami, malahan pelajar menghadapi kesukaran untuk membuat hubung-kait terhadap hasil pembelajaran bagi mata pelajaran Matematik dalam aktiviti harian (Yahya \& Amir, 2018). Dowker et al. (2019) berpendapat bahawa kebimbangan matematik juga dikenali sebagai sikap terhadap pembelajaran matematik. Sikap yang kerap kali dirujuk oleh seseorang pelajar dalam pembelajaran matematik adalah keyakinan, kekecewaan, ketidakpuasan, kebimbangan dan sebagainya (Husain, 2020). Keadaan sebegini seolah-olah menggambarkan perasaan bimbang terhadap pembelajaran matematik khususnya bagi mata pelajaran Matematik Tambahan akan 
sentiasa wujud selagi mereka takut pada kegagalan, keyakinan diri yang rendah, kelemahan menghadapi tekanan ujian, bersikap negatif dan pasif terhadap pembelajaran Matematik (Ding, 2016).

Sebagaimana yang kita ketahui, kebimbangan terhadap pembelajaran matematik tidak hanya melibatkan dari segi mental, bahkan juga dari segi fizikal akan turut berlaku. Sehubungan dengan itu, terdapat pelbagai aspek yang mungkin menjadi punca kebimbangan terhadap pembelajaran matematik termasuklah mata pelajaran Matematik itu sendiri, faktor individu dan kognitif serta sosial. Dengan erti kata yang lain, working memory merupakan salah satu penyebab bagi kebimbangan matematik yang boleh dikaitkan dengan faktor kognitif (Chang \& Beilock, 2016; Smart \& Linder, 2018; Yahya \& Amir, 2018). Selain itu, Greensfeld dan Deutsch (2020) pula menjelaskan bahawa faktor individu menjurus kepada motivasi pelajar, pengawalan kendiri, fisiologi, keyakinan dan gaya pembelajaran dalam Matematik serta sikap terhadap Matematik. Faktor sosial yang boleh mempengaruhi kebimbangan terhadap pembelajaran Matematik adalah sikap ibu bapa dan guru, isu yang berkaitan dengan kurikulum dan persekitaran (Chang \& Beilock, 2016; Gunderson et al., 2018).

Di samping itu, tahap efikasi kendiri pelajar terhadap pembelajaran matematik adalah berbeza-beza di antara satu sama lain. Dalam pembelajaran matematik, pelajar yang memiliki tahap efikasi kendiri yang tinggi akan melihat tugasan adalah sesuatu yang mudah dan mampu mengendalikan tugasan pada tahap kompetensi yang tinggi (Grigg et al., 2018). Bukan itu sahaja, Ozkal (2019) telah menjelaskan pelajar yang tinggi efikasi kendirinya dilihat lebih yakin semasa menyelesaikan tugasan matematik yang sukar dan mencabar. Hal ini berkemungkinan tugasan matematik yang diberi sesuai dengan kebolehan dan pencapaiannya. Perbezaan di antara pelajar yang mempunyai efikasi kendiri yang rendah dan efikasi kendiri yang tinggi. Efikasi kendiri juga boleh membantu memotivasikan pelajar untuk berkongsi pengetahuan dengan rakan sebaya (Orosco, 2016). Dalam konteks pembelajaran matematik, pelajar dengan adanya efikasi kendiri yang lebih tinggi, akan mewujudkan sikap yang positif untuk menyediakan lebih banyak pengetahuan yang berguna bagi pembelajaran matematik. Selain daripada itu, dengan adanya tahap penguasaan pengetahuan yang luas, seseorang pelajar itu akan lebih yakin dan gemar sewaktu pembelajaran dan pemudahcaraan bagi mata pelajaran Matematik dijalankan. Namun begitu, Gao (2020) yang menegaskan bahawa keadaan emosi yang tegang akan mempengaruhi tingkah laku seseorang pelajar. Oleh sebab itu, efikasi kendiri bagi para pelajar adalah amat penting dan perlu dititikberatkan oleh guru dan ibu bapa demi kerjaya mereka.

Tambahan lagi, kajian-kajian yang melibatkan efikasi kendiri pelajar dan kebimbangan matematik terhadap prestasi seseorang pelajar dalam pembelajaran matematik masih lagi diteruskan sehingga masa kini dalam berbagai-bagai peringkat pengajian pelajar (Deshler et al., 2019). Selain itu, Everingham et al. (2017), Masitoh dan Fitriyani (2018) serta Muwonge et. al. (2020) masing-masing melaksanakan kajian berkenaan kebimbangan matematik dan efikasi kendiri pelajar di peringkat sekolah menengah. Berdasarkan kajian Everingham et al. (2017) serta Masitoh dan Fitriyani (2018) menunjukkan bahawa efikasi kendiri pelajar serta tahap kebimbangan mereka memberi impak secara langsung terhadap pembelajaran matematik. Kajian-kajian ini juga dilaksanakan bagi meninjau efikasi kendiri pelajar dalam pembelajaran Matematik seperti keyakinan diri, kepentingan efikasi kendiri, keadaan emosi dan sebagainya untuk meningkatkan tahap efikasi kendiri seseorang pelajar dan mengurangkan tahap kebimbangan pelajar dalam proses pembelajaran matematik (Muwonge et. al., 2020).

Umum mengetahui bahawa terdapat hubungan yang rapat antara efikasi kendiri pelajar dengan kebimbangan matematik dalam pembelajaran. Pelbagai aspek yang mungkin terjadinya bagi efikasi kendiri dan kebimbangan terhadap pembelajaran matematik adalah seperti faktor sosial, kognitif dan individu. Faktor individu yang akan mempengaruhi tahap efikasi kendiri dan kebimbangan pelajar dalam pembelajaran matematik adalah seperti sikap pelajar terhadap Matematik, pengawalan kendiri pelajar dan motivasi pelajar dan sebagainya (Hamid, Baharum \& Sarkowi, 2020; Huang et al., 2019; Masitoh \& Fitriyani, 2018). Sama juga dengan faktor sosial yang mungkin menyumbang bagi efikasi kendiri dan kebimbangan terhadap matematik mencakupi aspek misalnya, kebimbangan terhadap pembelajaran guru dan ibu bapa serta persekitaran (Chang \& Beilock, 2016; Recber, Isiksal \& Koç, 2018; Soni \& Kumari, 2017). Tambahan pula, faktor mengenai kognitif yang menyebabkan kebimbangan terhadap matematik dikaitkan dengan working memory (Chang \& Beilock 2016; Jaafar \& Siti Mistima, 2020; Samuel \& Warner, 2019). Oleh itu, jelaslah menunjukkan terdapat berbagai-bagai faktor yang boleh memungkinkan 
terjadinya efikasi kendiri dan kebimbangan terhadap matematik dan haruslah dipandang secara teliti dan menyeluruh.

\section{Metod Kajian}

Kaedah kajian ini merupakan kaedah tinjauan (survey) yang melibatkan pengumpulan data kuantitatif daripada 311 orang pelajar tingkatan empat yang mengambil subjek Matematik Tambahan di lima buah Sekolah Menengah Kebangsaan (SMK) yang terletak di daerah Johor Bahru. Sampel kajian dipilih melalui dua teknik pensampelan iaitu pensampelan rawak mudah dan pensampelan kelompok dua tingkat. Menurut Yahaya et al. (2017), pensampelan kelompok dua tingkat (cluster sampling) boleh dilaksanakan di mana populasi yang melibatkan bilangan sampel kajian yang banyak dan senarai sampel kajian tidak diperoleh. Darussalam dan Hussin (2018) yang menjelaskan bahawa bilangan sampel kajian yang dipilih antara 30 hingga 500 orang adalah pemilihan yang paling sesuai dalam sesuatu kajian. Pemilihan sampel kajian adalah bertepatan dengan jadual penentuan saiz sampel Cohen et. al. (2001) bagi aras kesignifikanan $\mathrm{p}<0.05$. Selain itu, pemilihan lima buah sekolah ini adalah berdasarkan kriteria kajian yang telah dipertimbangkan seperti kos dan masa.

Instrumen kajian merupakan satu set soal selidik yang diadaptasi dan diubahsuai daripada May (2009), iaitu Mathematics Self-Efficacy and Anxiety Questionaire (MSEAQ). Instrumen soal selidik dalam kajian ini terdiri daripada dua bahagian, iaitu Bahagian A dan Bahagian B dan skala Likert dengan lima pilihan digunakan. Bahagian A dalam set soal selidik tersebut merupakan soalan berhubung kait dengan latar belakang responden yang melibatkan bangsa, jantina, gred ujian peperiksaan Matematik Moden dan Matematik Tambahan bulan Mac tingkatan empat serta bilangan jam membuat ulang kaji bagi mata pelajaran Matematik. Selain daripada bahagian A dalam instrumen kajian, bahagian B pula dibahagikan kepada dua konstruk untuk menilai tahap kebimbangan matematik dan tahap efikasi kendiri pelajar dengan pembelajaran matematik. Bukan itu sahaja, bahagian B juga mengandungi 26 item yang mengukur tahap kebimbangan pelajar terhadap pembelajaran matematik (13 item) dan tahap efikasi kendiri pelajar terhadap matematik (13 item) seperti Jadual 1. Tambahan lagi, item bagi kebimbangan efikasi kendiri pelajar terhadap pembelajaran matematik dalam soal selidik tersebut masing-masing mempunyai item positif dan item negatif. Dua orang pakar yang mempunyai kepakaran dalam bidang Matematik dan mahir kedua-dua bahasa dilantik untuk tujuan pengesahan kandungan instrumen. Hasil maklum balas daripada pakar digunakan sebagai penambahbaikan kepada instrumen kajian dari segi bahasa dan penggunaan subjek pada permulaan ayat supaya sesuai digunakan dalam konteks kajian di Malaysia.

Jadual 1: Perincian instrumen soal selidik

\begin{tabular}{ccccc}
\hline Bahagian & Aspek & No. Item & Bil. Item & Jumlah \\
\hline A & Latar belakang & $1-5$ & 5 & 5 \\
B & Tahap kebimbangan Matematik & $1-13$ & 13 & 26 \\
& Tahap efikasi kendiri pelajar & $13-26$ & 13 & 31 \\
\hline
\end{tabular}

Kajian rintis telah dijalankan ke atas 30 orang pelajar tingkatan empat dari sebuah sekolah Menengah di daerah Kulai, Johor. Hasil analisis dari ujian statistik kebolehpercayaan secara keseluruhannya mendapati nilai Alpha Cronbach yang diperolehi dalam kajian ini adalah 0.85. Menurut Norulbiah dan Effandi (2016), nilai Alpha Cronbach yang melebihi 0.6 boleh diterima kebolehpercayaannya. Memandangkan negara dilanda dengan penularan Covid-19 dan Perintah Kawalan Pergerakan (PKP) (Majlis Keselamatan Negara, 2020), proses pengumpulan data mengambil masa yang lebih lama. Kajian terhadap responden hanya boleh dijalankan pada bulan Julai 2020 apabila pelajar tingkatan empat menghadiri sekolah semula. Pengumpulan data memakan masa sehingga seminggu kerana sesetengah responden masih tidak hadir ke sekolah atas sebab kebimbangan bilangan kes Covid-19 masih tinggi. Oleh sebab itu, sejumlah 385 naskhah soal selidik telah diedarkan sama ada secara konvensional ataupun dalam bentuk 'Google Form' kepada lima buah sekolah yang terlibat. Walaupun pengaplikasian kemudahan teknologi memudahkan pengkaji mendapat semula respons dengan kadar lebih cepat, tetapi 
kaedah ini tidak bersesuaian dengan populasi kajian. Hal ini dapat dilihat hanya sejumlah 322 naskhah soal selidik yang telah dijawab dikembalikan, namun hanya terdapat 311 naskhah soal selidik dikenal pasti mempunyai data yang lengkap bagi peringkat seterusnya. Data ditapis sebelum dianalisis menggunakan perisian Statistical Package for Social Science (SPSS) versi 26.0. Analisis deskriptif seperti frekuensi dan peratus serta ujian korelasi Pearson digunakan untuk menjawab persoalan kajian berdasarkan data yang diperoleh.

\section{Hasil Kajian}

\section{Profil Responden Kajian}

Data yang telah diperoleh dalam kajian ini adalah 311 orang responden yang terpilih bagi menyertai penyelidikan ini. Jika diteliti lebih mendalam, hanya terdapat $128(41.2 \%)$ orang pelajar lelaki dan 183 (58.8\%) orang pelajar perempuan. Bahkan juga, kedua-dua jantina tidak memberikan kesan kepada dapatan kajian dalam tahap kebimbangan dan efikasi kendiri pelajar terhadap pembelajaran matematik. Keputusan subjek Matematik Moden dalam Bulan Mac tahun 2020 menunjukkan 48 (15.4\%) orang responden mendapat Gred A. Bilangan responden yang memperoleh Gred B adalah tertinggi, iaitu seramai $101(32.5 \%)$ orang responden, diikuti oleh Gred Cyang mencatatkan seramai $67(21.5 \%)$ orang responden dan $47(15.1 \%)$ orang responden mendapat Gred D. Seterusnya, responden mendapat Gred E dan Gred F masing-masing adalah seramai $24(7.7 \%)$ orang. Bagi keputusan subjek Matematik Tambahan dalam Bulan Mac tahun 2020 pula menunjukkan 33 (10.6\%) orang responden mendapat Gred A, diikuti oleh Gred B yang mencatatkan seramai $36(11.6 \%)$ orang responden. Bilangan responden yang memperoleh Gred C adalah tertinggi, iaitu seramai $72(23.2 \%)$ orang responden dan $62(19.9 \%)$ orang responden mendapat Gred D. Sehubungan itu, seramai $51(16.4 \%)$ orang responden mendapat Gred E dan $57(18.3 \%)$ pula mendapat Gred F. Secara umumnya, kajian mendapati bahawa taburan prestasi pelajar terhadap pembelajaran matematik adalah pada tahap lemah.

\section{Tahap Kebimbangan dan Efikasi Kendiri Pelajar Tingkatan Empat terhadap Pembelajaran Matematik}

Analisis deskriptif digunakan untuk menentukan tahap kebimbangan dan efikasi kendiri pelajar tingkatan empat terhadap pembelajaran matematik. Dapatan kajian mencatatkan skor kebimbangan pelajar dan skor efikasi kendiri pelajar terhadap pembelajaran matematik dipuratakan serta dikelaskan kepada tiga tahap, iaitu tahap tinggi, sederhana dan rendah berdasarkan Levin dan Rubin (dalam Darussalam \& Hussin 2018).

Jadual 2: Analisis deskriptif bagi tahap kebimbangan pelajar terhadap pembelajaran Matematik

\begin{tabular}{cccc}
\hline $\begin{array}{c}\text { Tahap Kebimbangan } \\
\text { Matematik }\end{array}$ & $\begin{array}{c}\text { Julat Skor } \\
\text { Min }\end{array}$ & Frekuensi (f) & $\begin{array}{c}\text { Peratusan } \\
(\%)\end{array}$ \\
\hline Tinggi & $3.68-5.00$ & 143 & 50.48 \\
Sederhana & $2.34-3.67$ & 157 & 45.98 \\
Rendah & $1.00-2.33$ & 11 & 3.54 \\
Jumlah & & 311 & 100 \\
\hline
\end{tabular}

Tahap kebimbangan pelajar terhadap pembelajaran matematik dalam kalangan 311 pelajar tingkatan empat yang dikaji seperti dalam Jadual 2. Sehubungan hasil dapatan yang diperoleh daripada instrumen kajian, didapati lebih daripada 50 peratus iaitu sebanyak $50.48 \%$ responden yang mempunyai tahap kebimbangan matematik yang tinggi. Selain itu, terdapat sebanyak $45.98 \%$ responden yang berada pada tahap kebimbangan yang sederhana manakala hanya terdapat $3.54 \%$ responden yang mempunyai tahap kebimbangan yang rendah terhadap pembelajaran matematik. Berdasarkan dapatan kajian, dapat disimpulkan bahawa majoriti pelajar tingkatan empat mempunyai tahap kebimbangan yang tinggi. Menurut Yang et. al. (2020), ramai pelajar menyatakan kebimbangan disebabkan penularan Covid-19 memberikan tekanan ketika mengikuti proses pengajaran dan pembelajaran dalam talian kerana kurang 
mendapat perhatian dan tumpuan. Kebanyakan pelajar sekolah menengah sukar memahami bahan yang disediakan oleh guru seperti video atau slaid semasa pembelajaran dalam talian terutamanya dalam mempelajari Matematik (Siron, Wibowo \& Narmadity, 2020). Kebimbangan pelajar boleh membawa pelbagai kesan terhadap pelajar tersebut seperti menggigil, mengelak dari menceburi bidang STEM, mengehadkan kapasiti working memory pelajar, hilang kepercayaan diri, menjejas kerjaya mereka dan sebagainya (Chang \& Beilock, 2016; Jaafar \& Siti Mistima, 2020; Samuel \& Warner, 2019).

Jadual 3: Analisis deskriptif bagi tahap efikasi kendiri pelajar terhadap pembelajaran Matematik

\begin{tabular}{|c|c|c|c|}
\hline Tahap Efikasi kendiri & Julat Skor Min & Frekuensi (f) & Peratusan (\%) \\
\hline Kerap & $3.68-5.00$ & 148 & 47.59 \\
\hline Kadang Kala & $2.34-3.67$ & 152 & 48.87 \\
\hline Jarang & $1.00-2.33$ & 11 & 3.54 \\
\hline Jumlah & & 311 & 100 \\
\hline
\end{tabular}

Selain dapatan kajian bagi tahap kebimbangan matematik dalam persoalan pertama, hasil analisis bagi item tahap efikasi kendiri terhadap pelajar tingkatan empat dalam pembelajaran matematik turut dikaji seperti Jadual 3. Melalui hasil analisis yang diperoleh bagi tahap efikasi kendiri pelajar terhadap pembelajaran matematik, terdapat sebanyak $47.59 \%$ responden yang berada pada tahap efikasi kendiri yang tinggi, diikuti dengan $48.87 \%$ responden yang berada pada tahap efikasi kendiri yang sederhana manakala hanya terdapat $3.54 \%$ responden yang mempunyai tahap efikasi kendiri yang rendah. Menurut Ali dan Hassan (2019), pelajar yang mempunyai tahap keyakinan diri dan motivasi yang sederhana tinggi dalam efikasi kendiri dapat menjangkakan sebarang masalah pembelajaran matematik mampu mereka mengatasinya serta mencapai matlamatnya. Oleh hal yang demikian, kecekapan dan keyakinan diri bergantung kepada keupayaan seseorang pelajar dalam merancang dan melaksanakan sebarang implikasi yang diperlukan bagi menghasilkan sesuatu tugasan yang lebih berkualiti. Hal ini juga selari dengan kajian Gao (2020) yang menegaskan bahawa sikap yang sedia ada pada seseorang pelajar dan kemahiran matematik merupakan kekangan kepada pembelajaran semasa amalan pengajaran dijalankan. Faktorfaktor yang mempengaruhi tahap kebimbangan dan tahap efikasi kendiri bagi seseorang pelajar masih lagi samar dan kajian lebih lanjut perlu dijalankan untuk menjawab persoalan ini. Secara keseluruhannya bagi persoalan pertama, keputusan analisis deskriptif menunjukkan bahawa sampel kajian iaitu pelajar tingkatan empat yang belajar di sekolah menengah di daerah Johor Bahru memiliki tahap kebimbangan yang tinggi dalam pembelajaran matematik. Selain itu, tahap efikasi kendiri pelajar terhadap pembelajaran bagi mata pelajaran Matematik adalah pada tahap yang sederhana.

\section{Hubungan antara Kebimbangan dengan Efikasi Kendiri Pelajar Tingkatan Empat terhadap Pembelajaran Matematik}

Plot Kebarangkalian Normal (Normal Probability Plot) yang dijalankan ke atas data menunjukkan taburan data adalah normal dengan semua titik berada pada sepanjang garisan bawah kiri sehingga ke garisan atas kanan. Bukan itu sahaja, andaian kehomogenan bagi varian ralat adalah bertaburan di sekitar 0 pada garis mendatarnya, maka masalah heteroskedastisiti tidak berlaku. Dengan erti kata lain, plot serakan tersebut telah menyatakan bahawa data adalah bertaburan normal. Oleh itu, Ujian Korelasi Pearson digunakan untuk menganalisis hubungan antara kebimbangan dengan efikasi kendiri pelajar tingkatan empat dalam pembelajaran matematik. Jadual 3 menunjukkan dapatan data bagi hubungan antara dua pemboleh ubah ini.

Jadual 4: Hubungan antara kebimbangan dengan efikasi kendiri pelajar tingkatan empat terhadap pembelajaran matematik

\begin{tabular}{llc}
\hline & & Efikasi kendiri Pelajar \\
\hline Kebimbangan terhadap Pembelajaran & Pekali Korelasi & .012 \\
Matematik & Sig. (2-tailed) & .827 \\
& $\mathrm{~N}$ & 311 \\
\hline
\end{tabular}


Berdasarkan Jadual 4, hasil dapatan kajian dapat ditunjukkan melalui analisis korelasi Pearson digunakan bagi mengenal pasti hubungan antara kebimbangan dengan efikasi kendiri pelajar tingkatan empat terhadap pembelajaran matematik. Hasil kajian ini menunjukkan tidak terdapat perhubungan yang signifikan antara kebimbangan dan efikasi kendiri terhadap pembelajaran matematik $(r=0.012, p=0.827$, $\mathrm{p}<0.05$ ) dalam kalangan pelajar Tingkatan Empat. Hasil dapatan ini telah menunjukkan bahawa tidak terdapat perkaitan secara langsung antara kebimbangan dengan efikasi kendiri pelajar tingkatan empat terhadap pembelajaran Matematik. Oleh itu, hipotesis nul tidak berjaya ditolak. Dengan kata lain, tahap kebimbangan tidak akan menjejaskan tahap efikasi kendiri terhadap pembelajaran matematik bagi pelajar Tingkatan Empat di daerah Johor Bahru. Hal ini selari dengan kajian yang dilakukan oleh Maher dan Adnan (2019) yang menjelaskan bahawa pelajar Omani mempunyai tahap efikasi kendiri yang tinggi dan kebimbangan terhadap pembelajaran matematik juga berada pada tahap yang tinggi. Dapatan ini bertentangan dengan dapatan kajian yang telah dijalankan oleh pengkaji-pengkaji lepas seperti Everingham et al. (2017), Foley et al. (2017) serta Huang et. al. (2020). Pengkaji-pengkaji tersebut menyatakan bahawa pelajar yang tinggi efikasi kendirinya mempunyai kebimbangan yang rendah dan dapat menghasilkan tugasan yang lebih berkualiti dalam pembelajaran matematik.

\section{Perbincangan Kajian}

Berdasarkan hasil kajian, kajian ini jelas sekali menunjukkan bahawa tahap kebimbangan terhadap pembelajaran matematik dalam kalangan pelajar tingkatan empat Sekolah Menengah Kebangsaan harian di daerah Johor Bahru berada pada tahap yang tinggi. Selain daripada itu, tahap efikasi kendiri dilihat secara keseluruhannya pula terletak pada tahap sederhana, tetapi menghampiri tinggi. Jika diteliti lebih mendalam, tahap kebimbangan yang tinggi ini bermaksud pelajar telah mengalami kebimbangan terhadap pembelajaran matematik pada aras yang tinggi. Manakala, tahap efikasi kendiri yang sederhana ini dapat dihuraikan bahawa pelajar masih mempunyai efikasi kendiri terhadap pembelajaran matematik namun pada aras yang rendah. Terdapat sejumlah besar pelajar yang mempunyai kebimbangan terhadap pembelajaran matematik yang tinggi dan perkara ini perlu dibendung oleh guru agar persepsi negatif ini tidak dibawa ke peringkat universiti dan akan mempengaruhi pembelajaran matematik pelajar tersebut di peringkat lebih tinggi. Justeru, faktor penyebab bagi menyatakan prestasi pelajar terhadap pembelajaran matematik yang kurang memuaskan selalu dikaitkan dengan sikap terhadap matematik (Husain, 2020; Kundu \& Ghose, 2016), faktor motivasi (Chang \& Beilock, 2016; Cribbs et al., 2020), status sosioekonomi (Husain, 2020), efikasi kendiri ( Grigg et.al., 2018; Gunderson et al., 2018; Hammoudi, 2019; Huang, Zhang \& Hudson, 2019) dan juga kebimbangan matematik (Huang, Zhang \& Hudson, 2019; Smart \& Linder, 2018; Yahya \& Amir, 2018).

Di samping itu, peningkatan prestasi mata pelajaran Matematik perlu diberi keutamaan kepada kefahaman berkenaan efikasi kendiri pada diri seseorang pelajar. Dengan erti kata lain, pelajar yang mempunyai tahap keyakinan diri dan motivasi yang tinggi dalam efikasi kendiri dapat menjangkakan sebarang masalah pembelajaran matematik mampu mereka mengatasinya serta mencapai matlamatnya (Justicia-Galiano et. al., 2017). Namun demikian, tidak terdapat perhubungan yang signifikan mengenai kebimbangan dengan efikasi kendiri terhadap pembelajaran matematik bagi pelajar tingkatan empat tersebut. Dapatan ini bertentangan dengan dapatan kajian yang telah dijalankan oleh pengkaji-pengkaji lepas seperti Everingham et al. (2017), Masitoh dan Fitriyani (2018) serta Rahmi et al. (2017). Pada hakikatnya, efikasi kendiri dan kebimbangan matematik saling berhubung kait antara satu sama lain. Hanya dalam kajian Malaysia sering menggunakan perkataan yang berbeza-beza ataupun sebahagian daripada efikasi kendiri. Mengikut kajian Roslan dan Siti Mistima (2019), dapatan kajian jelas menunjukkan bahawa pelajar berefikasi kendiri yang tinggi mempunyai kebimbangan terhadap matematik yang rendah dan sebaliknya. Hal ini bermakna pelajar yang tinggi efikasi kendirinya mempunyai kebimbangan yang rendah dan dapat menghasilkan tugasan yang lebih berkualiti dalam pembelajaran matematik. Menurut Schober et al. (2018), sikap yang sedia ada pada seseorang pelajar dan kemahiran matematik merupakan kekangan kepada pembelajaran semasa amalan pengajaran dijalankan. Faktor sikap pelajar yang negatif iaitu kehilangan keyakinan dan keupayaan diri terhadap pembelajaran matematik akan mengganggu kehidupan seseorang pelajar. Oleh itu, pelajar hendaklah meningkatkan kesedaran diri terhadap tahap 
kebimbangan dan tahap efikasi kendiri pelajar dalam meningkatkan prestasi serta pembelajaran matematik mereka.

Cadangan kajian yang dinyatakan oleh Joy (2019) adalah pihak sekolah harus membantu menetapkan semula matlamat dan minda pelajar terhadap pembelajaran matematik. Kebimbangan yang dihadapi pelajar dapat dileraikan dengan memberi peluang kepada pelajar untuk menyertai bengkel-bengkel keberkesanan dan motivasi. Perkara ini dapat menerapkan motivasi, pencapaian dan ketahanan pelajar dalam matematik. Selain daripadaitu, sokongan daripada ibu bapa dan keluarga merupakan nadi kekuatan bagi seorang pelajar. Keyakinan dan kepercayaan diri dapat membentuk efikasi kendiri pelajar apabila mereka dapat berinteraksi dan berbincang bersama keluarga mengenai masalah yang dihadapi dalam matematik (Macmull \& Ashkenazi, 2019). Latar belakang keluarga juga merupakan impak yang besar kepada kebimbangan terhadap pembelajaran matematik seperti kajian Husain (2020) menegaskan bahawa pelajar yang tinggal bersama keluarga yang tidak memberi sokongan akan memberikan kesan kepada pelajar untuk mengatasi kesukaran dalam pelajaran. Sokongan sosial yang diterima daripada pihak sekolah dan rakan sebaya mampu mengekalkan keyakinan diri sendiri serta menjadi lebih produktif dan melaksanakan amanah yang diberi.

Sebagaimana yang kita ketahui, guru harus melaksanakan sesi pengajaran secara ansur maju bagi membantu pelajar menguasai konsep Matematik (Livers et.al., 2020). Guru harus peka dan prihatin terhadap keperluan perbezaan individu yang wujud dalam kalangan pelajar agar setiap individu diberi peluang untuk mengembangkan kebolehan masing-masing dalam bidang Matematik. Pendek kata, kajian ini amat penting bagi pihak berkenaan seperti ibu bapa, guru serta pelajar sendiri menyedari wujudnya kebimbangan dalam pembelajaran matematik serta keyakinan dan sikap seseorang pelajar perlu dipertingkatkan lagi tanpa memandang rendah akan kepentingan efikasi kendiri. Lanjutan daripada huraian yang telah dinyatakan, langkah intervensi perlu dirangka supaya situasi sebegini dapat dikawal dengan baik serta dapat memberi ruang dan peluang untuk menjayakan kerjaya kelak.

\section{Kesimpulan}

Hasil keseluruhan yang diperoleh, didapati bahawa terdapat tahap kebimbangan pelajar terhadap pembelajaran matematik adalah pada tahap yang tinggi. Selain daripada itu, hasil kajian mendapati bahawa tahap efikasi kendiri terhadap pelajar Tingkatan Empat dalam pembelajaran matematik pula berada pada kadar sederhana. Namun demikian, tidak terdapat hubungan yang signifikan antara kebimbangan dengan efikasi kendiri pelajar Tingkatan Empat terhadap pembelajaran matematik. Sehubungan itu, sebenarnya kewujudan kebimbangan terhadap pembelajaran matematik disebabkan pelajar sering menghadapi kesukaran dalam mengusai konsep matematik menjadikan pelajar tersebut kurang berkeyakinan pada diri sendiri serta tidak percaya kebolehan diri yang sedia ada. Selain itu, kebolehan menguasai ilmu matematik memerlukan teknik pembelajaran dan pengetahuan serta kesungguhan. Ilmu matematik memiliki ciri-ciri abstrak yang menyebabkan kebanyakan pelajar tanpa mengira di Malaysia malah di seluruh dunia menganggap Matematik merupakan satu mata pelajaran yang sukar dan menakutkan. Hal ini membawa kepada implikasi praktikal dan teoretikal untuk meningkatkan kapasiti pelajar menghadapi cabaran, halangan dan kesukaran dalam proses pembelajaran Matematik. Dapatan kajian ini juga memberikan implikasi dari aspek teori khusus tentang pengaruh antara pemboleh ubah yang terlibat dalam kajian ini. Pihak-pihak yang berkaitan termasuklah pelajar, guru, sekolah, kurikulum mahupun pihak-pihak yang berkenaan seharusnya menjadikan implikasi praktikal dan teoretikal kajian ini sebagai rujukan untuk meningkatkan efikasi kendiri pelajar dan mengurangkan kebimbangan dalam pembelajaran matematik.

\section{Rujukan}

Abdul Hamid, H., Baharum, M., \& Sarkowi, A. (2020). Pengaruh efikasi kendiri terhadap motivasi dan pencapaian akademik siswa pendidik. Jurnal IPDA, 26(1), 104-112. 
Ali, N. A. M., \& Hassan, N. C. (2019). Mathematics Anxiety and Mathematics Motivation among Students in the Faculty of Science of a Public University in Malaysia. International Journal of Academic Research in Progressive Education and Development, 8(4), 952-963.

Arshad, M. N., Atan, N. A., Abdullah, A. H., Abu, M. S., \& Mokhtar, M. (2017). Improving the reasoning skills of students to overcome learning difficulties in additional Mathematics: a Review. Journal of Science and Mathematics Letters, 5, 28-35.

Awang, L. A., Tarmizi, R. A., \& Ayob, A. F. M. (2016). Effectiveness Of Using Logo Programming For Learning Mathematics In Geometric Topics On Form Two Students'achievement (1-12). Jurnal Pendidikan Sains dan Matematik Malaysia, 6(1), 1-12.

Bandura, A. (2010). Self-efficacy. The Corsini encyclopedia of psychology, 1-3.

Bartley, S. R., \& Ingram, N. (2018). Parental modelling of mathematical affect: self-efficacy and emotional arousal. Mathematics Education Research Journal, 30(3), 277-297.

Batchelor, S., Torbeyns, J., \& Verschaffel, L. (2019). Affect and mathematics in young children: an introduction. Educational Studies in Mathematics, 100(3), 201-209.

Bhowmick, S., Young, J. A., Clark, P. W., \& Bhowmick, N. (2017). Marketing Students' Mathematics Performance: The Mediating Role of Math Anxiety on Math Self-Concept and Math Self-Efficacy. Journal of Higher Education Theory and Practice, 17(9), 104-117.

Caviola, S., Carey, E., Mammarella, I. C., \& Szucs, D. (2017). Stress, Time Pressure, Strategy Selection and Math Anxiety in Mathematics: A Review of the Literature. Frontiers in Psychology, 8, 14881488 .

Chang, H., \& Beilock, S. L. (2016). The math anxiety-math performance link and its relation to individual and environmental factors: A review of current behavioral and psychophysiological research. Current Opinion in Behavioral Sciences, 10, 33-38.

Chien, P. L. K., \& Lajium, D. A. D. (2016). The Effectiveness of Science, Technology, Engineering and Mathematics (STEM) Learning Approach Among Secondary School Students. In International Conference on Education and Psychology 2016 (ICEduPsy16) (pp. 95-104).

Chua, Y. P (2013). Asas statistik penyelidikan: Analisis data skala Likert. (2 $2^{\text {nd }}$ ed.). Malaysia: McGrawHill Education (Malaysia) Sdn. Bhd.

Chua, Y. P. (2014a). Asas statistik penyelidikan. (3 ${ }^{\text {rd }}$ ed.). Malaysia: McGraw-Hill Education (Malaysia) Sdn. Bhd.

Chua, Y. P. (2014b). Kaedah penyelidikan. ( $3^{\text {rd }}$ ed.). Malaysia: McGraw-Hill Education (Malaysia) Sdn. Bhd.

Cribbs, J., Hazari, Z., Sonnert, G., \& Sadler, P. M. (2020). College students' mathematics-related career intentions and high school mathematics pedagogy through the lens of identity. Mathematics Education Research Journal, 1-28.

Darusalam, G. \& Hussin, S. (2018). Metodologi penyelidikan dalam pendidikan: Amalan dan analisis kajian. ( $2^{\text {nd }}$ ed.). Kuala Lumpur: Penerbit Universiti Malaya.

Deshler, J., Fuller, E., \& Darrah, M. (2019). Affective states of university developmental mathematics students and their impact on self-efficacy, belonging, career identity, success and persistence. International Journal of Research in Undergraduate Mathematics Education, 5(3), 337-358.

Ding, Y. (2016). Measuring developmental students' mathematics anxiety. Research and Teaching in Developmental Education, 31-47.

Dowker, A., Cheriton, O., Horton, R., \& Mark, W. (2019). Relationships between attitudes and performance in young children's mathematics. Educational Studies in Mathematics, 100(3), 211230.

Durksen, T. L., Way, J., Bobis, J., Anderson, J., Skilling, K., \& Martin, A. J. (2017). Motivation and engagement in mathematics: a qualitative framework for teacher-student interactions. Mathematics Education Research Journal, 29(2), 163-181.

Everingham, Y. L., Gyuris, E., \& Connolly, S. R. (2017). Enhancing student engagement to positively impact mathematics anxiety, confidence and achievement for interdisciplinary science subjects. International Journal of Mathematical Education in Science and Technology, 48(8), 1153-1165.

Foley, A. E., Herts, J. B., Borgonovi, F., Guerriero, S., Levine, S. C., \& Beilock, S. L. (2017). The math anxiety-performance link: A global phenomenon. Current Directions in Psychological Science, 26(1), 52-58. 
Gabriel, M. H., Atkins, D., Chokshi, A., Midence, S., \& Bowdon, M. (2019). Exploring Math Anxiety and Math Self-Efficacy among Health Administration Students. Journal of Health Administration Education, 36(2), 151-168.

Gao, J. (2020). Sources of mathematics self-efficacy in Chinese students: a mixed-method study with Qsorting procedure. International Journal of Science and Mathematics Education, 18(4), 713-732.

Greensfeld, H., \& Deutsch, Z. (2020). Mathematical challenges and the positive emotions they engender. Mathematics Education Research Journal, 1-22.

Grigg, S., Perera, H. N., McIlveen, P., \& Svetleff, Z. (2018). Relations among math self efficacy, interest, intentions, and achievement: A social cognitive perspective. Contemporary Educational Psychology, $53,73-86$.

Gunderson, E. A., Park, D., Maloney, E. A., Beilock, S. L., \& Levine, S. C. (2018). Reciprocal relations among motivational frameworks, math anxiety, and math achievement in early elementary school. Journal of Cognition and Development, 19(1), 21-46.

Hair, J. F., Black, W. C., Babin, B. J., Anderson, R. E., \& Tatham, R. (2010). Multivariate data analysis. Multivariate Data Analysis. Pearson.

Hammoudi, M. M. (2020). Measurement of students' mathematics motivation and self-concept at institutions of higher education: evidence of reliability and validity. International Journal of Mathematical Education in Science and Technology, 51(1), 63-86.

Huang, X., Zhang, J., \& Hudson, L. (2019). Impact of math self-efficacy, math anxiety, and growth mindset on math and science career interest for middle school students: the gender moderating effect. European Journal of Psychology of Education, 34(3), 621-640.

Husain, K. (2020). Kebimbangan Matematik Dengan Pencapaian Matematik Dan Faktor Demografi Dalam Kalangan Pelajar Matrikulasi. Jurnal Dedikasi, 14, 89-121.

Jaafar, W. N. W., \& Maat, S. M. (2020). Hubungan antara motivasi dengan pencapaian matematik dalam kalangan murid sekolah luar bandar. Jurnal Pendidikan Sains Dan Matematik Malaysia, 10(1), 3948.

Joy, U. C. (2019). Achievement Motivation And Emotional Intelligence As Predictors Of Mathematical Resilience Among Secondary School Students. Advances in Social Sciences Research Journal, 6(5), 191-200.

Justicia-Galiano, M. J., Martín-Puga, M. E., Linares, R., \& Pelegrina, S. (2017). Math anxiety and math performance in children: The mediating roles of working memory and math self-concept. British Journal of Educational Psychology, 87(4), 573-589.

Kementerian Pendidikan Malaysia. (2015). Dokumen standard kurikulum dan pentaksiran matematik tingkatan 1. Putrajaya: Bahagian Pembangunan Kurikulum.

Kundu, A., \& Ghose, A. (2016). The relationship between attitude and self-efficacy in mathematics among higher secondary students. Journal of Humanities and Social Science, 21(4), 25-31.

Laurens, T., Batlolona, F. A., Batlolona, J. R., \& Leasa, M. (2017). How does realistic mathematics education (RME) improve students' mathematics cognitive achievement?. Eurasia Journal of Mathematics, Science and Technology Education, 14(2), 569-578.

Livers, S. D., Zelkowski, J., Harbour, K. E., McDaniel, S. C., \& Gleason, J. (2020). An examination of the relationships of mathematics self-efficacy and teaching practices among elementary, secondary, and special education educators. Investigations in Mathematics Learning, 12(2), 96-109.

Lukowski, S. L., DiTrapani, J., Jeon, M., Wang, Z., Schenker, V. J., Doran, M. M., ... \& Petrill, S. A. (2019). Multidimensionality in the measurement of math-specific anxiety and its relationship with mathematical performance. Learning and individual differences, 70, 228-235.

Macmull, M. S., \& Ashkenazi, S. (2019). Math Anxiety: The Relationship Between Parenting Style and Math Self-Efficacy. Frontiers in Psychology, 10, 1721-1721.

Majlis Keselamatan Negara. (2020). Kenyataan media majlis keselamatan negara, jabatan perdana menteri. Retrieved from https://www.pmo.gov.my/wp-content/uploads/2020/03/PergerakanKawalan-Covid19-amended-18032020-UPDATED-12.12AM.pdf.pdf.

Marham, M. A., Mohd Ayub, A. F., \& Ahmad Tarmizi, R. (2016). Keterlibatan murid kolej vokasional berpencapaian rendah dalam pengajaran dan pembelajaran Matematik menerusi pendekatan 'QMethodology'. Jurnal Pendidikan Sains dan Matematik Malaysia (JPSMM UPSI), 6(1), 41-57.

Masitoh, L. F., \& Fitriyani, H. (2018). Improving students' mathematics self-efficacy through problem based learning. Malikussaleh Journal of Mathematics Learning (MJML), 1(1), 26-30. 
May, D. K. (2009). Mathematics self-efficacy and anxiety questionnaire (Doctoral dissertation, University of Georgia).

Mulenga, E. M., \& Marbán, J. M. (2020). Is COVID-19 the gateway for digital learning in mathematics education? Contemporary Educational Technology, 12(2), ep269.

Mutlu, Y. (2019). Math anxiety in students with and without math learning difficulties. International Electronic Journal of Elementary Education, 11(5), 471-475.

Mutisya, E. N., Kinai, T. K., Dinga, J. N., \& Mutweleli, S. M. (2016). Relationship between Academic Emotions, Self-efficacy and mathematics achievement of secondary school students in Central Division, Machakos County, Kenya. Msingi Journal, 1(2), 29-57.

Muwonge, C. M., Ssenyonga, J., \& Kwarikunda, D. (2018). Cognitive appraisals, achievement emotions, and motivation towards learning mathematics among lower secondary students. African Journal of Research in Mathematics, Science and Technology Education, 22(2), 243-253.

Ngah, N., \& Zakaria, E. (2016). Keupayaan pelajar dalam menjana masalah, menyelesaikan masalah matematik dan sikap pelajar terhadap penyelesaian masalah. Jurnal Pendidikan Matematik, 4(1), 116.

OECD. (2013). Mathematics self-beliefs and participation in mathematics-related activities. PISA 2012 Results: Ready to Learn (Volume III), Students' Engagement, Drive and Self-Beliefs, 87-112.

Orosco, M. J. (2016). Measuring elementary student's mathematics motivation: a validity study. International Journal of Science and Mathematics Education, 14(5), 945-958.

Ozkal, N. (2019). Relationships between self-efficacy beliefs, engagement and academic performance in math lessons. Cypriot Journal of Educational Sciences, 14(2), 190-200.

Peixoto, F., Sanches, C., Mata, L., \& Monteiro, V. (2017). “How do you feel about math?”: Relationships between competence and value appraisals, achievement emotions and academic achievement. European Journal of Psychology of Education, 32(3), 385-405.

Puteh, M. \& Khalin, S. Z. (2016). Mathematics anxiety and its relationship with the achievement of secondary students in Malaysia. International Journal of Social Science and Humanity, 6(2), 119.

Rahmi, S., Nadia, R., Hasibah, B., \& Hidayat, W. (2017). The relation between self-efficacy toward math with the math communication competence. Infinity Journal, 6(2), 177-182.

Ramirez, G., Shaw, S. T., \& Maloney, E. A. (2018). Math anxiety: Past research, promising interventions, and a new interpretation framework. Educational Psychologist, 53(3), 145-164.

Recber, S., Isiksal, M., \& Koç, Y. (2018). Investigating self-efficacy, anxiety, attitudes and mathematics achievement regarding gender and school type. Anales de Psicología/Annals of Psychology, 34(1), 41-51.

Reimer, D., Sortkear, B., Oskarsson, M., Nilsen, T., Rasmusson, M., \& Nissinen, K. (2018). Northern Lights on TIMSS and PISA 2018. Nordic Council of Ministers.

Roslan, N. A., \& Maat, S. M. (2019). Systematic Literature Review on Secondary School Students' Mathematics Self-Efficacy. Sciences, 8(4), 975-987.

Russo, J., \& Hopkins, S. (2017). Student reflections on learning with challenging tasks:'I think the worksheets were just for practice, and the challenges were for maths'. Mathematics Education Research Journal, 29(3), 283-311.

Samuel, T. S., \& Warner, J. (2019). "I Can Math!”: Reducing Math Anxiety and Increasing Math SelfEfficacy Using a Mindfulness and Growth Mindset-Based Intervention in First-Year Students. Community College Journal of Research and Practice, 1-18.

Saravani, S., Marziyeh, A., \& Jenaabadi, H. (2017). The Relationship of the Dimensions of Perceived Teaching Style with Students' Mathematics Achievement and Self-Efficacy. International Electronic Journal of Mathematics Education, 12(2), 99-109.

Sevgi, S., \& Arslan, K. (2020). Exploring Middle School Students Mathematics Self-Efficacy and Mathematics Anxiety. Online Submission, 7(2), 41-61.

Siron, Y., Wibowo, A., \& Narmaditya, B. S. (2020). Factors affecting the adoption of e-learning in Indonesia: Lesson from Covid-19. JOTSE: Journal of Technology and Science Education, 10(2), 282-295.

Skilling, K., Bobis, J., \& Martin, A. J. (2020). The "ins and outs" of student engagement in mathematics: shifts in engagement factors among high and low achievers. Mathematics Education Research Journal, 1-25. 
Smart, J., \& Linder, S. M. (2018). Development, validation, and implementation of the elementary mathematics motivation inventory (EMMI): examining motivational constructs in elementary mathematics. Fields Mathematics Education Journal, 3(1), 1-14.

Soni, A., \& Kumari, S. (2017). The role of parental math anxiety and math attitude in their children's math achievement. International Journal of Science and Mathematics Education, 15(2), 331-347.

Wakefield, N., Champion, J., Bolkema, J., \& Dailey, D. (2018). Diagnostic Effects of an Early Mastery Activity in College Algebra and Precalculus. International Journal of Research in Undergraduate Mathematics Education, 4(3), 376-392.

Yahaya, A., Voo, P., Maakip, I., \& Malek, M. D. A. (2017). Kaedah penyelidikan dalam pendidikan. Tanjong Malim: Pejabat Karang Mengarang UPSI.

Yahya, S. Z. \& Amir, R. (2018). Kebimbangan matematik dan pencapaian matematik Tambahan [Mathematics anxiety and additional mathematics performance]. Journal of Nusantara Studies (JONUS), 3(2), 124-133.

Yang, X., Zhang, M., Kong, L., Wang, Q., \& Hong, J. C. (2020). The Effects of Scientific Self-efficacy and Cognitive Anxiety on Science Engagement with the "Question-Observation-Doing-Explanation" Model during School Disruption in COVID-19 Pandemic. Journal of Science Education and Technology, 1-14. 